\title{
PELATIHAN PELESTARIAN BENDA CAGAR BUDAYA DALAM PENGEMBANGAN PARIWISATA BUDAYA BAGI APARAT DESA RADEY DAN PAKUWERU DI KECAMATAN TENGA MINAHASA SELATAN
}

\author{
H.Onibala \\ Fakultas Ilmu Sosial, Universitas Negeri Manado
}

\begin{abstract}
Dipandang dari segi geografis wilayah Kecamatan Tenga Minahasa Selatan memiliki berbagai macam situs budaya yang sangat baik untuk dikembangkan sbagai daerah wisata. Daerah ini merupakan daerah yang berada disekitar daerah pegunungan yang sangat strategis untuk tempat ting gal orang Minahasa dahulu yang menurut cerita rakyat turun temurun mengungkapkan tempat ting gal pertama nenek moyang orang Minahasa yang sebelumnya ting gal didaerah Wulurmaatus dan menamakan diri orang Malesung. Benda Cagar Budaya di daerah ini sudah mulai disentuh oleh pemerintah untuk melestarikannya tetapi masih terbatas pada menjaga karena umumnya benda benda cagar budaya di daerah ini masih terbiar.

Situs Benda Cagar Budaya di Minahasa Selatan sampai saat ini belum digarap sebagai sumber ilmu pengetahuan dan sumber daya dalam pembangunan Minahasa Selatan lebih khusus pembangunan di sektor Pendidikan dan kepariwisataan. Untuk itu dibutuhkan upaya terpadu dengan masyarakat setempat Aparat Desa untuk menjadi penggerak masyarakat untuk dapat berpartisipasi melestarikan situs Benda cagar Budaya yang tersebar di sekitarnya.

Tujuan yang hendak dicapai dalam pelaksanaan ini adalah:

1. Untuk menyelamatkan dan melestarikan situs-Cagar Budaya yang tersebar di Kecamatan Tenga Kabupaten Minahasa Selatan, sebagai salah satu bukti otentik sejarah budaya dengan melibatkan masyarakat setempat secara aktif. 2. Untuk memasyarakatkan Undang-Undang Nomor 5 Tahun 1992.

Metode yang digunakan dalam kegiatan ini adalah ceramah, tanya jawab, dan praktik cara pelestarian, yang diikuti oleh 16 orang peserta yang mewakili pemilik tanah dimana situs Benda Cagar Budaya itu berada, tokoh masyarakat, dan Aparat Desa di Kecamatan Tenga Kabupaten Minahasa Selatan .

Pelatihan dan Penyuluhan ini mendapat respons dan antusias masyarakat karena dalam pelatihan dan penyuluhan ini banyak masyarakat yang bertanya tentang cara pelestarian dan bahkan banyak yang mengungkapkan tempat-tempat situs berada yang belum teridentifikasi. Respons masyarakat juga terlihat dari usulan tentang pelaksanaan tentang penelusuran jalur perjalanan nenek moyang orang Minahasa yang dikenal tinggal di Malesung di masa purba Minahasa.
\end{abstract}

Keywords: Pelestarian benda cagar budaya 


\section{PENDAHULUAN}

\section{A. Analisis Situasi}

Bangsa Indonesia memiliki berbagai ragam budaya dan budaya bangsa itu dibentuk dari unggulan-unggulan yang ada pada budayabudaya daerah se-Nusantara. Dengan demikian budaya-budaya daerah yang ada di Nusantara muncul dan eksis lebih dulu, sedangkan budaya bangsa muncul sesudahnya, tepatnya sesudah Negara Republik Kesatuan Indonesia diproklamirkan. Dengan demikian budaya bangsa mewarisi nilai-nilai unggulan dari budaya-budaya daerah, dan bukan sebaliknya. Budaya-budaya daerah yang ada di Indonesia selanjutnya menjadi warisan budaya (cultural heritage) bagi bangsa Indonesia seperti yang terdapat didaerah Sulawesi Utara dan lebih khusus di Minahasa yang memiliki situs Benda Cagar Budaya.

Dipandang dari segi geografis wilayah Kecamatan Tenga Minahasa Selatan memiliki berbagai macam situs budaya yang sangat baik untuk dikembangkan sbagai daerah wisata. Daerah ini merupakan daerah yang berada disekitar daerah pegunungan yang sangat strategis untuk tempat tinggal orang Minahasa dahulu yang menurut cerita rakyat turun temurun mengungkapkan tempat tinggal pertama nenek moyang orang Minahasa yang sebelumnya tinggal didaerah Wulurmaatus dan menamakan diri orang Malesung. Benda Cagar Budaya di daerah ini sudah mulai disentuh oleh pemerintah untuk melestarikannya tetapi masih terbatas pada menjaga karena umumnya benda benda cagar budaya di daerah ini masih terbiar. Situs Benda Cagar Budaya di Minahasa Selatan sampai saat ini belum digarap sebagai sumber ilmu pengetahuan dan sumber daya dalam pembangunan Minahasa Selatan lebih khusus pembangunan di sektor Pendidikan dan kepariwisataan.

Pelestarian situs Benda Cagar Budaya Minahasa Selatan sampai saat ini lebih banyak mengangkat situs Benda Cagar Budaya di daerah Minahasa Induk dan Minahasa Utara terutama tentang situs waruga sebagai tempat makam orang Minahasa dahulu, termasuk situs Watu Pinabetengan. Sedangkan situs benda Cagar Budaya dalam kegiatan penyuluhan pelestarian ini akan lebih di fokuskan pada lokasi Kecamatan Tenga yang memiliki situs Benda Cagar Budaya.
Menurut cerita turun temurun tempat tinggal awal nenek moyang orang Minahasa terdapat didaerah Lolombulan serta daerah Pegunungan Wulurmahatus, dan menyebar di kawasan Minahasa melalui jalur Sungai Ranoyapo, Amurang, Tumpaan dan masuk daerah Kiawa kemudian menyebar keseluruh Minahasa khususnya didaerah Watu Pinabetengan serta melalui tempat tersebut inilah terdapat rangkaian situs Benda Cagar Budaya yang perlu dilestarikan untuk kepentingan ilmu dan kepariwisataan di Minahasa Selatan'

Dengan demikian keberadaan situs Benda Cagar Budaya tersebut sangat perlu dilestarikan agar dapat bermanfaat bagi generasi sekarang dan yang akan datang sebagai:

1. Sumber Sejarah Budaya

2. Warisan Budaya

3. Sumber Belajar bagi siswa

4. Obyek Wisata lokal dan Nasional.

5. Bahan kajian seni budaya dan ilmu pengetahuan

Universitas Negeri Manado khususnya Jurusan Pendidikan IPS sebagai lembaga Pendidikan Tinggi di Sulawesi Utara yang mempunyai misi dalam pengembangan pembangunan di Sulawesi Utara, seyogianya bertanggung jawab dan melakukan usaha terpadu untuk bekerja sama melibatkan masyarakat dalam upaya melestarikan situs situs sejarah budaya yang tersebar daerahnya.

Untuk itu dibutuhkan upaya terpadu dengan masyarakat setempat Aparat Desa untuk menjadi penggerak masyarakat untuk dapat berpartisipasi melestarikan situs Benda cagar Budaya yang tersebar di sekitarnya.

Tujuan yang hendak dicapai dalam pelaksanaan ini adalah:

1. Untuk menyelamatkan dan melestarikan situs-Cagar Budaya yang tersebar di Kecamatan Tenga Kabupaten Minahasa Selatan, sebagai salah satu bukti otentik sejarah budaya dengan melibatkan masyarakat setempat secara aktif.

2. Untuk memberi pelatihan tentang arti penting situs Benda Cagar Budaya kepada tokoh masyarakat dan aparat pemerintah di Kecamatan Tenga Kabupaten Minahasa Selatan, agar tercipta kepedulian atas bendabenda tersebut,

3. Untuk memasyarakatkan Undang-Undang Nomor 5 Tahun 1992. 
Manfaat penelitian ini adalah :

1. Sebagai aset warisan budaya dan sumber ilmu pengetahuan.

2. Sebagai aset wisata, ekonomis, etnik dan estetika.

3. Agar masyarakat dapat memahami, menghargai dan melestarikan nilai-nila $\mathrm{i}$ budaya bangsa.

Metode yang digunakan dalam kegiatan ini adalah ceramah, tanya jawab, dan praktik cara pelestarian, yang diikuti oleh 16 orang peserta yang mewakili pemilik tanah dimana situs Benda Cagar Budaya itu berada, tokoh masyarakat, dan Aparat Desa Radey dan Pakuweru di Kecamatan Tenga Kabupaten Minahasa Selatan .

\section{KAJIAN LITERATUR DAN PEGEMBANGAN HIPOTESIS}

\section{A. Kajian Teori}

Masyarakat terbentuk melalui sejarah yang panjang, perjalanan berliku, tapak demi tapak. Pada titik-titik tertentu terdapat peninggalanpeninggalan yang eksis atau terekam sampai sekarang yang kemudian menjadi warisan budaya. Warisan budaya, menurut Davidson (1991:2) diartikan sebagai 'produk atau hasil budaya fisik dari tradisi- tradisi yang berbeda dan prestasi-prestasi spiritual dalam bentuk nilai dari masa lalu yang menjadi elemen pokok dalam jatidiri suatu kelompok atau bangsa'. Jadi warisan budaya merupakan hasil budaya fisik dan nilai budaya dari masa lalu.

Nilai budaya dari masa lalu inilah yang berasal dari budaya-budaya lokal yang ada di Nusantara, meliputi: tradisi, cerita rakyat dan legenda, bahasa ibu, sejarah lisan, kreativitas (tari, lagu, drama pertunjukan), kemampuan beradaptasi dan keunikan masyarakat setempat (Galla, 2001: 12)

Kata lokal disini tidak mengacu pada wilayah geografis, khususnya kabupaten/kota, dengan batas-batas administratif yang jelas, tetapi lebih mengacu pada wilayah budaya yang seringkali melebihi wilayah administratif dan juga tidak mempunyai garis perbatasan yang tegas dengan wilayah budaya lainnya seperti yang di kenal dengan budaya atau adat Tontemboan. Kata budaya lokal juga bisa mengacu pada budaya milik penduduk asli (inlander) yang telah dipandang sebagai warisan budaya.

Berhubung pelaku pemerintahan Republik Indonesia adalah bangsa sendiri, maka warisan budaya yang ada menjadi milik bersama. Ini berbeda situasinya dengan Negara Australia dan Amerika yang warisan budayanya menjadi milik penduduk asli secara eksklusif sehingga penduduk asli mempunyai hak untuk melarang setiap kegiatan pemanfaatan yang akan berdampak buruk pada warisan budaya mereka (Frankel, 1984). Warisan budaya fisik sering diklasifikasikan menjadi warisan budaya tidak bergerak dan warisan budaya bergerak.

Warisan budaya tidak bergerak biasanya berada di tempat terbuka dan terdiri dari: situs, tempattempat bersejarah, bentang alam darat maupun air, bangunan kuno dan/atau bersejarah, patungpatung pahlawan (Galla, 2001: 8). Warisan budaya bergerak biasanya berada di dalam ruangan dan terdiri dari: benda warisan budaya, karya seni, arsip, dokumen, dan foto, karya tulis cetak, audiovisual berupa kaset, video, dan film (Galla, 2001: 10).

Warisan budaya fisik dalam pasal 1 Undangundang Nomor 5 tahun 1992 tentang Benda Cagar Budaya disebut sebagai 'benda cagar budaya' yang berupa benda buatan manusia dan benda alam yang dianggap mempunyai nilai penting bagi sejarah, ilmu pengetahuan dan kebudayaan, sedangkan lokasi yang mengandung atau diduga mengandung benda cagar budaya disebut 'situs' (pasal 2 Undangundang Nomor 5 tahun 1992). Benda cagar budaya dan situs dipelajari secara khusus dalam disiplin ilmu Arkeologi yang berupaya mengungkapkan kehidupan manusia di masa lalu melalui benda-benda yang ditinggalkannya. Ini berbeda dengan disiplin ilmu Sejarah yang berupaya mengungkapkan kehidupan manusia di masa lalu melalui bukti-bukti tertulis yang ditinggalkannya.

\section{B. Pelestarian Situs Budaya}

Beragam wujud warisan budaya lokal memberi kita kesempatan untuk mempelajari kearifan lokal dalam mengatasi masalah-masalah yang dihadapi di masa lalu. Masalahnya kearifan local tersebut seringkali diabaikan, dianggap tidak ada relevansinya dengan masa sekarang apalagi masa depan. Dampaknya adalah banyak warisan budaya yang lapuk dimakan usia, terlantar, terabaikan bahkan dilecehkan keberadaannya. Padahal banyak bangsa yang kurang kuat sejarahnya justru mencari-cari jatidirinya dari tinggalan sejarah dan warisan budayanya yang sedikit jumlahnya. Kita 
sendiri, bangsa Indonesia, yang kaya dengan warisan budaya justru mengabaikan asset yang tidak ternilai tersebut, dan sungguh merupakan kondisi yang kontradiktif.

Kita sebagai bangsa dengan jejak perjalanan sejarah yang panjang sehingga kaya dengan keanekaragaman budaya seharusnya berusaha untuk melestarikan warisan budaya yang sampai kepada kita. Melestarikan tidak berarti membuat sesuatu menjadi awet dan tidak mungkin punah. Melestarikan berarti memelihara untuk waktu yang sangat lama. Jadi upaya pelestarian warisan budaya lokal berarti upaya memelihara warisan budaya lokal untuk waktu yang sangat lama . Karena upaya pelestarian merupakan upaya memelihara untuk waktu yang sangat lama maka perlu dikembangkan pelestarian sebagai upaya yang berkelanjutan (sustainable).

Dengan demikian bukan pelestarian yang hanya mode sesaat, berbasis proyek, berbasis donor dan elitis (tanpa akar yang kuat di masyarakat). Pelestarian tidak akan dapat bertahan dan berkembang jika tidak didukung oleh masyarakat luas dan tidak menjadi bagian nyata dari kehidupan kita. Para pakar pelestarian harus turun dari menara gadingnya dan merangkul masyarakat menjadi pecinta pelestarian yang bergairah. Pelestarian jangan hanya tinggal dalam buku tebal disertasi para doktor, jangan hanya diperbincangkan dalam seminar para intelektual di hotel mewah, apalagi hanya menjadi hobi para orang kaya. Pelestarian harus hidup dan berkembang di masyarakat. Pelestarian harus diperjuangkan oleh masyarakat luas (Hadiwinoto, 2002: 30).

Secara singkat pelestarian akan dapat dikatakan berkelanjutan (sustainable) jika berbasis pada kekuatan dalam, kekuatan lokal, kekuatan swadaya. Karenanya sangat diperlukan penggerak, pemerhati, pecinta dan pendukung dari berbagai lapisan masyarakat. Untuk itu perlu ditumbuh-kembangkan motivasi yang kuat untuk ikut tergerak berpartisipasi melaksanakan pelestarian, antara lain:

1. Motivasi untuk menjaga, mempertahankan dan mewariskan warisan budaya yang diwarisinya dari generasi sebelumnya;

2. Motivasi untuk meningkatkan pengetahuan dan kecintaan generasi penerus bangsa terhadap nilai-nilai sejarah kepribadian bangsa dari masa ke masa melalui pewarisan khasanah budaya dan nilai-nilai budaya secara nyata yang dapat dilihat, dikenang dan dihayati;

3. Motivasi untuk menjamin terwujudnya keragaman budaya daerah;

4. Motivasi ekonomi yang percaya bahwa nilai budaya local akan meningkat bila terpelihara dengan baik sehingga memiliki nilai komersial untuk meningkatkan kesejahteraan masyarakat; dan

5. Motivasi simbolis yang meyakini bahwa budaya lokal adalah manifestasi dari jati diri suatu kelompok atau masyarakat sehingga dapat menumbuh-kembangkan rasa kebanggaan, harga diri dan percaya diri yang kuat.

Dari penjelasan di atas dapat diketahui bahwa pelestarian situs sejarah budaya juga mempunyai muatan ideologis yaitu sebagai gerakan untuk mengukuhkan kebudayaan, sejarah dan identitas suku bangsa juga sebagai penumbuh kepedulian masyarakat untuk mendorong munculnya rasa memiliki masa lalu yang sama diantara anggota komunitas.

Pada lokasi Situs Benda Cagar Budaya di Desa Radey dan Pakuweru Kecamatan Tenga ini terdapat peninggalan purbakala berupa Watu Tumotowa, lesung batu,Waruga, menhir dan benda-benda peninggalan purbakala tersebut dalam kondisi ada yang tidak terawat.

Karena adanya keterbatasan sumber daya maka kegiatan ini pada dasarnya lebih merupakan upaya untuk memunculkan kesadaran masyarakat desa di sekitar situs dalam melestarikan situs yang secara umum dilaksanakan dengan mengadakan kegiatan penyuluhan dan pelatihan lapangan

Kerangka pemecahan masalah dalam pelaksanaan kegiatan ini adalah :

1. Mengadakan penyuluhan terhadap aparat pemerintahan dan masyarakat.

2. Memberikan contoh kepada masyarakat supaya lebih memiliki kepedulian terhadap keberadaan situs sebagai benda cagar budaya.

3. Memberikan contoh kepada masyarakat mengenai tindakan-tindakan yang perlu dilakukan terhadap situs-situs yang ada sesuai dengan ketentuan yang terdapat dalam Undang-Undang Nomor 5 Tahun 1992 tentang Pelestarian Situs sebagai Benda Cagar Budaya. 
4. Memberikan pengarahan dan petunjuk kepada masyarakat apabila terjadi pengrusakan, pencurian, atau penemuan Situs, Benda Cagar Budaya sesuai dengan ketentuan yang terdapat dalam UndangUndang Nomor 5 Tahun 1992.

Pelatihan dan Penyuluhan merupakan upaya untuk memberikan penerangan secara detail kepada masyarakat terkait dengan pelestarian situs atau benda cagar budaya yang ada di sekitar mereka.

Metode yang digunakan dalam kegiatan ini adalah ceramah, tanya jawab dan praktek lapangan berupa pembersihan langsung pada situs yang ada di sekitar lokasi pelatihan.

\section{HASIL DAN PEMBAHASAN}

Pelatihan dalam kegiatan ini dilaksanakan di kompleks Kantor Desa Radey dan Pakuweru yang dikuti oleh Aparat Desa dan Kecamatan serta masyarakat sekitar situs dan penjaga Situs. Metode yang digunakan ditempat pelatihan adalah Ceramah dan Tanya jawab, Diskusi terbuka.

Pelaksanaan di tempat umum ini dimaksudkan agar masyarakat umum dapat langsung mengetahui tentang bagaimana pemeliharaan atau pelestarian situs berdasarkan UndangUndang Nomor 5 Tahun 1992 dan masyarakat mengetahui bahwa pemerintah telah menetapkan perangkat hukum yang mengatur tentang pelestarian situs sebagai benda cagar budaya. Dengan demikian masyarakat menge tahui dan sadar bahwa mereka tidak lagi memperlakukan situs atau benda cagar budaya menurut kehendak mereka sendiri atau menjadikan tempat situs ini sebagai tempat penyembahan berhala. Melalui penyuluhan ini masyarakat terhindar darihal hal yang bertentangan dengan ajaran agama.

Pelatihan dan Penyuluhan ini mendapat respons dan antusias masyarakat karena dalam pelatihan dan penyuluhan ini banyak masyarakat yang bertanya tentang cara pelestarian dan bahkan banyak yang mengungkapkan tempat-tempat situs berada yang belum teridentifikasi. Respons masyarakat juga terlihat dari usulan tentang pelaksanaan tentang penelusuran jalur perjalanan nenek moyang orang Minahasa yang dikenal tinggal di Malesung di masa purba Minahasa.
Keberhasilan pelatihan dan penyuluhan ini tidak lepas dari kepedulian masyarakat terhadap pelestarian nilai-nilai budaya termasuk nilainilai seni. Dengan adanya kepedulian masyarakat, kesepahaman antara penyuluh dan masyarakat mengenai tujuan dilaksanakannya pelatihan maka terjalin hubungan yang baik untuk pengembangan pelestarian situs sejarah budaya di Kecamatan Radey dan Pakuweru. Masyarakat mengusulkan agar pemerintah daerah untuk memperhatikan pemeliharaan benda benda cagar budaya yang tersebar di desa desa Kecamatan Tenga. Selain penyuluhan secara formal pada masyarakat juga pada tempat tertentu dimana ada pertemuan kecil dengan para pemuda atau dengan bapak-bapak sehingga kami mendapat masukan tentang situs-situs yang ada ditempat mereka melihat dan bahkan menemukan. Hal ini kami lakukan juga untuk lebih menjalin keakraban dengan masyarakat sehingga memudahkan terjadinya komunikasi untuk mengungkapkan keberadaan situs-situs yang ada.

Suatu hal yang menarik adalah bahwa banyak anak anak, pemuda dan masyarakat desa yang mengenal benda benda cagar budaya di wilayah kecamatan Radey dan Pakuweru Kabupaten Minahasa Selatan..

Direncanakan untuk kelanjutan kegiatan ini akan dipasang papan nama pada setiap situs ang bertulisan "Situs Benda Cagar Budaya Dilindungi Oleh Negara", dan diharapkan kepada pengunjung situs ini dapat berpartisipasi dalam pelestariannya, serta tidak mengotori atau merusaknya. Dalam pertemuan dan penyuluhan masyarakat mengusulkan agar pemerintah menyediakan biaya pemeliharaan secara terus menerus serta penyuluhan secara bertahap agar masyarakat tidak menggunakan situs sebagai tempat menyembah berhala.

Di Kecamatan Radey dan Pakuweru belum ada situs yang dikelola sebagai tempat wisata.

\section{KESIMPULAN DAN SARAN}

\section{A. Kesimpulan}

Situs Benda Cagar Budaya yang beraneka ragam di daerah sekitar Kecamatan Ranoyapo merupakan warisan budaya yang perlu dilestarikan karena memiliki nilai budaya yang tinggi. Setelah mengadakan kegiatan penyuluhan dan pelatihan tentang pentingnya pelestarian situs budaya di Kecamatan Tenga ternyata aparat pemerintah desa dan tokoh 
masyarakat mengetahui bahwa disekitarnya terdapat situs yang sesungguhnya memiliki arti penting bagi pembangunan multidimesional bangsa dan negara. Dengan pengetahuan yang dimiliki melalui penyuluhan ini masyarakat dan aparat desa di kecamatan Ranoyapo akan memiliki kepedulian terhadap situs budaya yang ada disekitarnya.

Pelestarian ini merupakan awal untuk kita mengenal pentingnya pelestarian situs budaya di Minahasa Selatan, sehingga melalui kegiatan ini diharapkan masyarakat di Kecamatan Radey dan Pakuweru dapat memasyarakatkan pelestarian situs-situs yang ada dan diharapkan jika menemukan benda purba sebaiknya melaporkan kepada pemerintah atau pihak berwajib.

\section{B. Saran}

a. Perlu adanya perhatian pemerintah terhadap keberadaan situs-situs di Kecamatan Radey dan Pakuweru bahkan di Minahasa Selatan pada umumnya.

b. Pemerintah Desa Sekitar situs perlu berkoordinasi dengan instansi terkait untuk melaksanakan pelestarian situs budaya yang ada Kecamatan Radey dan Pakuweru dan didaerah Minahasa Selatan pada umumnya.

\section{REFERENSI}

Agus Dono Karmadi, 2011, Budaya Lokal, Jakarta

Frankel, D. 1984. "Who Owns the Past?". Australian Society, 3 (9).

Galla, A. 2001. Guidebookfor the Participation of Young People in Heritage

Conservation. Brisbane: Hall and jones Advertising.

Hadiwinoto, S. "Beberapa Aspek Pelestarian Warisan Budaya". Makalah disampaikan pada Seminar Pelestarian dan Pengembangan Masjid Agung Demak, di Demak, 17 Januari 2002.

Habib Mustopo, 2003, Undang Undang Benda Cagar Budaya dan Masalah Konservasi, dalam Seminar Regional Eksistensi Cagar Budaya sebagai Aset Sejarah di Tengah Arus globalisasi, Jember, Jawa tengah.

Lubis Mochtar,1980, Bangsa Indonesia, Jakarta: Yayasan Idayu.

Lapian A,B, 1989, Bertha Pantouw, Latar Belakang Sejarah Kebudayaan Minahasa,
Dalam Jurnal Ilmu Sosial dan Humaniora, FISIP UNSRAT., 1997

Mamengko Roy E.,12002, Etnik Minahasa dalam Akselerasi Perubahan, Jakarta, Pustaka Sinar Harapan

Onibala L.H,2012, Toar Lumimuut dalam Sejarah dan Legenda, dalam Seminar Kajian Sejarah Budaya Manado

Peursen,C A. van,1976, Strategi Kebudayaan, Terjemahan Dick Hartoko, Jakarta: BPK Gunung Mulia.

Sondakh A J,S, 2003, Si Tou Timou Tumou Tou, Jakarta, Pustaka Sinar Harapan

Smith, L. 1996. "Significance Concepts in Australian Management Archaeology" dalam L. Smith dan A. Clarke (eds). Issue in Management Archaeology, Tempus, vol 5.

Undang-undang Nomor 5 tahun 1992 tentang Benda Cagar Budaya.

World Heritage Unit. 1985. Australia's World Heritage. Canberra: Department of Environment, Sports and Territories.

http://www.javanologi.info/main/themes/image s/pdf/Budaya_Lokal-, Agus pdf, 2011 